\title{
Evaluation of the effect of platelet rich plasma (PRP) on enhancement of bone healing in diaphyseal bone defects by radiography and computed tomography
}

\author{
Ahmet ÖZAK ${ }^{1}$, Cenk YARDIMCI ${ }^{1}$, Özlem H. NISBET ${ }^{1}$, İlkay Koray BAYRAK ${ }^{2}$ Cevat NíSBET $^{3}$ \\ ${ }^{1}$ Department of Surgery, Faculty of Veterinary Medicine, Ondokuz Mayıs University; 2 Department of Radiology, Faculty of \\ Medicine, Ondokuz Mayıs University; 3 Department of Biochemistry, Faculty of Veterinary Medicine, Ondokuz May1s University.
}

Summary: The effect of platelet-rich plasma (PRP) with autogenous cancellous bone graft on enhancement of bone healing in diaphyseal bone defects was evaluated. A 4-mm defect was created in the middiaphysis of the tibias of 20 rabbits. Rabbits were divided into two groups of ten animals each: only autogenous cancellous graft, PRP and autogenous cancellous graft. In animals of group 1, only autogenous cancellous grafts, and to those in group 2, PRP and autogenous cancellous grafts, were applied to the defect. Radiographical and computed tomography (CT) views were taken and evaluated on postoperative days $0,15,30,60$, and 90 . According to the bone formation, union, and remodeling scores, group 1 had better scores than group 2 on days 30, 60, and 90. The density was significantly increased on day 60 than on days 0,15 , and 30 in group 1 . In conclusion, it was evaluated that PRP could not enhance the bone regeneration in diaphyseal defects when used with autogenous cancellous bone graft.

Key words: Bone regeneration, computed tomography (CT), platelet rich plasma (PRP), radiography.

\section{Diyafizeal kemik defektlerinde trombositten zengin plazmanın (PRP) kemik iyileşmesini artırma üzerindeki etkisinin radyografi ve bilgisayarlı tomografi ile değerlendirilmesi}

Özet: Bu çalışmada; trombositten zengin plazmanın (PRP), otojen kansellöz greftler ile birlikte diyafizer defektlerde kemik rejenerasyonuna olan etkisi değerlendirildi. Yirmi tavşanda tibianın orta $1 / 3$ diyafizinde $4 \mathrm{~mm}$. genişliğinde defekt oluşturuldu. Tavşanlar, her birinde 10 tavşan içeren iki gruba ayrıldı, birinci gruptaki tavşanlara sadece otojenöz kansellöz greft, ikinci gruptakilere PRP ile birlikte otojenöz kansellöz greft yerleştirildi. Operasyon sonrası 0., 15., 30., 60. ve 90. günlerde radyografi ve bilgisayarlı tomografi (BT) çekimleri yapıldı ve değerlendirildi. Kemik oluşumu, kaynama ve yeniden şekillenme derecelendirmesine göre 30., 60. ve 90. günlerde birinci grupta, ikinci gruba göre daha iyi sonuçlar elde edildi. Birinci grupta dansite, 60 . günde 0 ., 15. ve 30. güne göre daha belirgin bir artış gösterdi. Sonuç olarak; PRP, otojenöz kansellöz greftler ile birlikte diyafizer kemik defektlerine uygulandığında, kemik rejenerasyonunu artırıcı hiçbir katkısı olmadığı anlaşıldı.

Anahtar sözcükler: Bilgisayarlı tomografi (BT), kemik rejenerasyonu, radyografi trombositten zengin plazma (PRP).

\section{Introduction}

The treatment of massive bone defects is the most challenging problem. Long-bone defects, resulting from trauma, tumors, osteitis, implant loosening, or corrective osteotomies, require surgical interventions, because spontaneous regeneration is limited to relatively small defects. Autogenous bone grafting is accepted as the gold standard for treatment of bone defects; additionally, mineral bone substitutes and callus distraction are the most commonly used techniques $(10,20)$.

Growth factors influence chemotaxis, differentiation, proliferation, and synthetic activity of bone cells, thereby regulating physiological remodeling and fracture healing (16). In 1998, Marx et al. (14) used PRP as a source of autogenous thrombocytic growth factors for the reconstruction of maxillofacial defects in humans and found that PRP resulted in faster maturation of autogenous bone transplants and higher bone density. The effects of PRP have been mainly investigated in the mandible, calvarium, long bones with cylindrical defects $(5,6,17,22)$. However, a few studies have been evaluated the effect of PRP in the diaphyseal defects of long bones $(10,19,20)$.

The aim of this study was to evaluate the effect of PRP with autogenous cancellous graft on enhancement of bone regeneration in the defects of long-bones by radiography and computed tomography.

\section{Materials and Methods}

Surgery: Twenty adult New Zealand white rabbits were used and kept in separate cages, fed a standard diet, water ad libitum and allowed to move freely during the study. Animal selection, management, and experimental protocol were approved by the Animal Research Ethics 
Committee at the Ondokuz Mayis University of Turkey. The rabbits were divided to two groups; each of ten rabbits. The rabbits were premedicated with an intramusculary injection of $3 \mathrm{mg} / \mathrm{kg}$ xylazine hydrochloride and induced $44 \mathrm{mg} / \mathrm{kg}$ ketamine hydrochlorure. Anesthesia was maintained using 2-3\% isoflurane under spontaneous ventilation with facemask. Six Kirschner wires $(\varnothing 1.5 \mathrm{~mm})$ were used for bilateral external fixator configuration. Tibia was exposed through by a medial approach, and a $4 \mathrm{~mm}$ middiaphyseal ostectomy was created out by a high-speed burr. During this procedure, sterile saline was used to avoid burn injury of the bone. In group 1, the gap was filled by autogenous cancellous graft, only which was maintained from the iliac crest, and in the second group, both PRP and autogenous cancellous graft were placed to the gap. Cefazolin sodium $(20 \mathrm{mg} / \mathrm{kg}$, im) was administered to all animals once just before the operation and every $24 \mathrm{~h}$ for 4 days postoperatively for antibiotic therapy.

PRP preparation: A total of $10 \mathrm{ml}$ of blood was taken from each rabbit by venipuncture of the ramus intermedius of $\mathrm{v}$. auricularis caudalis before surgery, and on alternate days. Preparation and activation of PRP were conducted according to the techniques as described by Katz et al (11). The average peripheral blood platelet count was $307.000 / \mathrm{mm}^{3}$, with a range from 217.000 to 405.000. The mean platelet count of the PRP was $1.206 .000 / \mathrm{mm}^{3}$, with a range from 644.000 to 2.518 .000 .

Three dimensional computed tomography analyses: On postoperative days $0,15,30,60$, and 90 , rabbits were anesthetized with an intramusculary injection of $3 \mathrm{mg} / \mathrm{kg}$ xylazine hydrochloride and $44 \mathrm{mg} / \mathrm{kg}$ ketamine hydrochlorure and placed on the computed tomography (CT) machine in ventral recumbency (CT, Aquilion, Toshiba, Japan). The operated tibia was scanned with a 16-slice multidetector CT system. Scanning parameters for the complete tibia were as follows: collimation: $20 \mathrm{x}$ $1 \mathrm{~mm}$; reconstruction interval: $0.5 \mathrm{~mm}$; tube rotation period: $0.4 \mathrm{~s} ; 120 \mathrm{kV}$, and $70 \mathrm{mAs}$. All images from the CT scans were loaded onto a workstation (Vitrea 2, Vital Images Inc., Plymouth, MN, USA). The sagittal reformatted images of the ostectomy site were obtained. The posterior, anterior, lateral, and medial distances of the ostectomy site were measured. On the median sagittal plane, the region of interest was placed to include the entire fracture site, and the mean Hounsfield unit (HU) density was measured. For comparison, the HU density of a normal bone between the first two metal bars of the external fixator was used.

Radiographic analyses: The radiographs of the operated tibia were obtained using a Basic 100-30 device (Intermedical, Italy) after the $\mathrm{CT}$ analyses on the same days. Rabbits were anesthetized by the same protocol, and the tibias were positioned in the anteroposterior direction. X-ray exposure was maintained constant for all animals: $50 \mathrm{kV}$ and $0.5 \mathrm{mAs}$. The evaluation of the radiographic views was conducted according to the scoring system that proposed by Lane et al (12). According to this scoring system, bone formation, union, and remodeling were scored as: No evidence of bone formation: 0 , Bone formation occupying $25 \%$ of the defect: 1, Bone formation occupying $50 \%$ of the defect: 2, Bone formation occupying $75 \%$ of the defect: 3 , Full gap formation: 4, Full fracture line: 0, Partial fracture line: 2, Absent fracture line: 4, No remodeling: 0, Remodeling of the intramedullary channel: 2, Full remodeling of cortex: 4 .

Statistical analyses: The student's t-test was used to compare the anterior, posterior, lateral and medial distances of the gap and density results of both groups on days $15,30,60$, and 90 . The results of the groups on different days were compared by ANOVA (one-way variance analysis). The significance of the difference between the groups was controlled by the Duncan's test. The Fisher score test was used to evaluate the radiographic results (9).

\section{Results}

Four rabbits in group 1 and 5 rabbits in group 2 were dead at the end of day 60 , because of coccidiosis.

\section{Radiographic Results}

Postoperative $15^{\text {th }}$ day: No difference was detected in both groups in relation to bone formation, union, and remodeling.

Postoperative $30^{\text {th }}$ day: In group 1 , grade- 3 bone formation was detected in $60 \%$ of the rabbits $(n=6)$, However, in group 2, grade-2 bone formation was observed in $60 \%$ of the rabbits $(n=6)$. Bone formation in grade- 3 and grade- 2 union were significant $(\mathrm{p}<0.05)$ in group 1 . However, no remodeling was seen in both groups.

Postoperative $60^{\text {th }}$ day: Grade- 4 bone formation was revealed in $60 \%$ of the rabbits in group 1 and statistically it was more significant than group $2(p<0.05)$. Grade- 4 union and grade- 2 unions were observed in 5 animals each in group $1(50 \%)$. However, in group 2, grade- 2 and grade- 4 unions were possed in $70 \%(n=7)$ and $20 \%(\mathrm{n}=2)$ of the rabbits, respectively.

Postoperative $90^{\text {th }}$ day: In all rabbits of the first group $(\mathrm{n}=6)$, grade- 4 bone formation and union were observed (Figure 1). In group 2, bone-formation scoring was distributed as $60 \%$ with grade- $4(\mathrm{n}=3), 20 \%$ with grade- $3(n=1), 20 \%$ with grade- $2(n=1)$.

Radiographic scoring results were presented in table 1. 
Table 1. Radiographic scoring results (statistically significant scores $(\mathrm{p}<0.05)$ are marked with an asteriks) BF: Bone formation, U: Union, R: Remodeling, NA: Not avaliable

Tablo 1. Radyografik derecelendirme sonuçları (istatistiksel olarak belirgin dereceler $(\mathrm{p}<0.05)$ yıldız ile işaretlenmiştir, BF: Kemik oluşumu, U: Kaynama, R: Yeniden şekillenme

\begin{tabular}{|c|c|c|c|c|c|c|c|c|c|c|c|c|c|c|c|c|c|c|c|c|c|c|c|c|}
\hline \multirow[t]{2}{*}{ Group 1} & & & & \multicolumn{21}{|c|}{ Group 2} \\
\hline & \multicolumn{3}{|c|}{ Day 15} & \multicolumn{3}{|c|}{ Day 30} & \multicolumn{3}{|c|}{ Day 60} & \multicolumn{3}{|c|}{ Day 90} & \multicolumn{3}{|c|}{ Day 15} & \multicolumn{3}{|c|}{ Day 30} & \multicolumn{3}{|c|}{ Day 60} & \multicolumn{3}{|c|}{ Day 90} \\
\hline Case no & $\mathrm{BF}$ & U & $\mathrm{R}$ & $\mathrm{BF}$ & $\mathrm{U}$ & $\mathrm{R}$ & $\mathrm{BF}$ & U & $\mathrm{R}$ & $\mathrm{BF}$ & $\mathrm{R}$ & $\mathrm{U}$ & $\mathrm{BF}$ & $\mathrm{R}$ & U & $\mathrm{BF}$ & $\mathrm{R}$ & $\mathrm{U}$ & $\mathrm{BF}$ & $\mathrm{R}$ & $\mathrm{U}$ & $\mathrm{BF}$ & $\mathrm{R}$ & $\mathrm{U}$ \\
\hline 1 & 1 & 0 & 0 & $3^{*}$ & 2 & 0 & $4^{*}$ & 2 & 2 & 4 & 4 & 2 & 1 & 0 & 0 & 1 & 0 & 0 & 3 & 2 & 0 & 4 & 4 & 2 \\
\hline 2 & 1 & 0 & 0 & $3^{*}$ & 2 & 0 & 3 & 2 & 0 & 4 & 4 & 2 & 1 & 0 & 0 & 1 & 0 & 0 & 3 & 2 & 0 & NA & NA & NA \\
\hline 3 & 1 & 0 & 0 & $2^{*}$ & 0 & 0 & 3 & 2 & 0 & 4 & 4 & 0 & 1 & 0 & 0 & 2 & 0 & 0 & 3 & 2 & 0 & 4 & 4 & 0 \\
\hline 4 & 1 & 0 & 0 & $3^{*}$ & 2 & 0 & $4^{*}$ & 4 & 0 & 4 & 4 & 2 & 1 & 0 & 0 & 2 & 0 & 0 & 3 & 2 & 0 & NA & NA & NA \\
\hline 5 & 1 & 0 & 0 & $3^{*}$ & 2 & 0 & $4^{*}$ & 4 & 0 & NA & NA & NA & 1 & 0 & 0 & 2 & 2 & 0 & 3 & 2 & 0 & NA & NA & NA \\
\hline 6 & 1 & 0 & 0 & $2^{*}$ & 2 & 0 & $4^{*}$ & 4 & 0 & 4 & 4 & 2 & 1 & 0 & 0 & 1 & 0 & 0 & 2 & 0 & 0 & 2 & 0 & 0 \\
\hline 7 & 2 & 0 & 0 & $3^{*}$ & 2 & 0 & $4^{*}$ & 4 & 0 & NA & NA & NA & 1 & 0 & 0 & 2 & 2 & 0 & 3 & 2 & 0 & 3 & 2 & 0 \\
\hline 8 & 2 & 0 & 0 & $3^{*}$ & 2 & 0 & $4^{*}$ & 4 & 0 & 4 & 4 & 2 & 1 & 0 & 0 & 2 & 2 & 0 & 4 & 4 & 0 & 4 & 4 & 2 \\
\hline 9 & 1 & 0 & 0 & $2^{*}$ & 2 & 0 & 3 & 2 & 0 & NA & NA & NA & 1 & 0 & 0 & 2 & 2 & 0 & 3 & 2 & 0 & NA & NA & NA \\
\hline 10 & 1 & 0 & 0 & $2^{*}$ & 2 & 0 & 3 & 2 & 0 & NA & NA & NA & 1 & 0 & 0 & 3 & 2 & 0 & 4 & 4 & 0 & NA & NA & NA \\
\hline
\end{tabular}

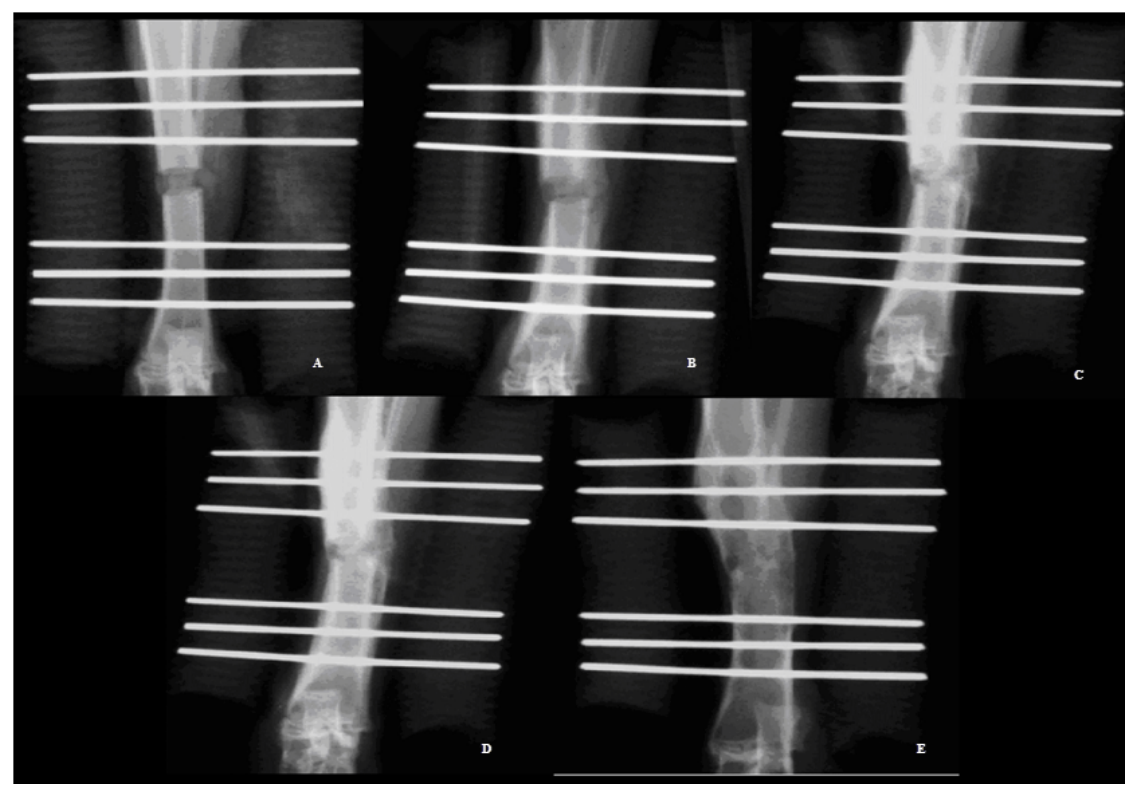

Figure 1. Radiographic view of case no:6 in group 1 on postoperative days 0 (a), 15 (b), 30 (c), 60 (d), 90 (e).

Şekil 1. Grup 1'de 6 nolu olgunun operasyon sonras1 0. (a), 15. (b), 30. (b), 60. (c), 90. (e) günlerdeki radyografik görüntüleri.

Figure 2. Three dimensional CT appearance of case no: 6 in group 1 on postoperative days 0 (a), 15 (b), 30 (c), 60 (d), 90 (e).

Şekil 2. Grup 2'de 6 nolu olgunun operasyon sonras1 0. (a), 15. (b), 30. (b), 60. (c), 90. (e) günlerde üç boyutlu bilgisayarlı tomografik görüntüleri.

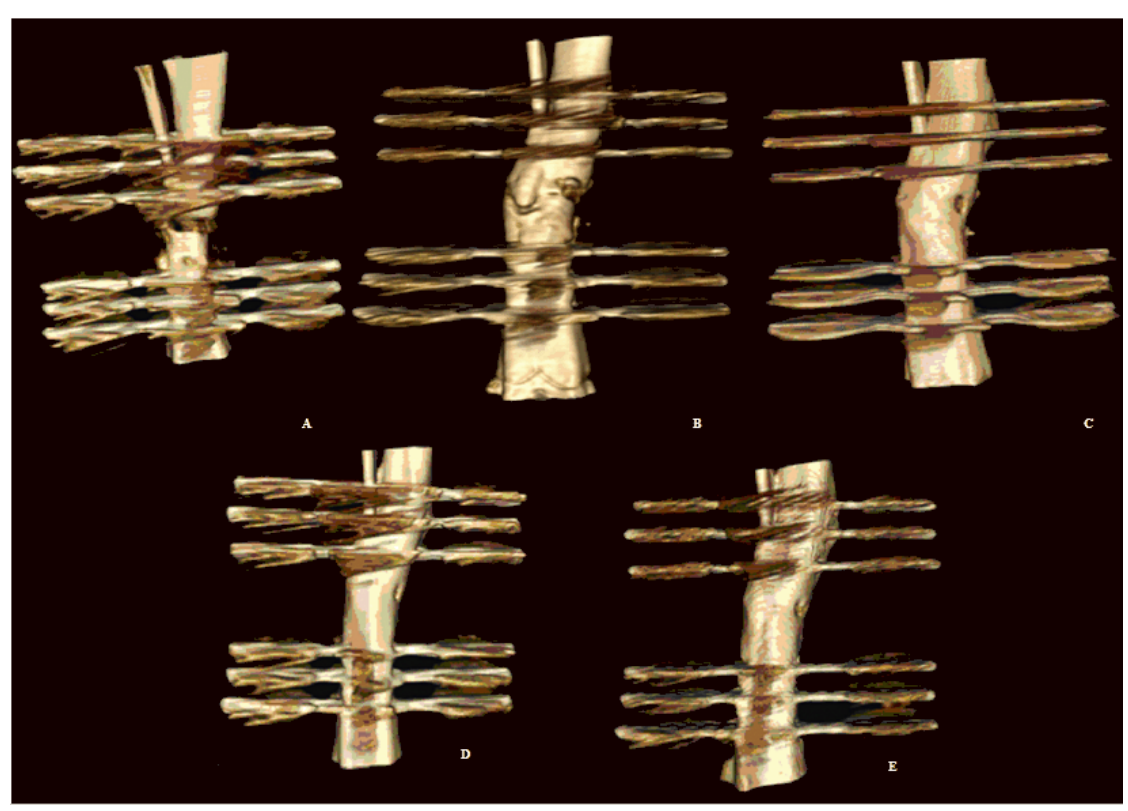




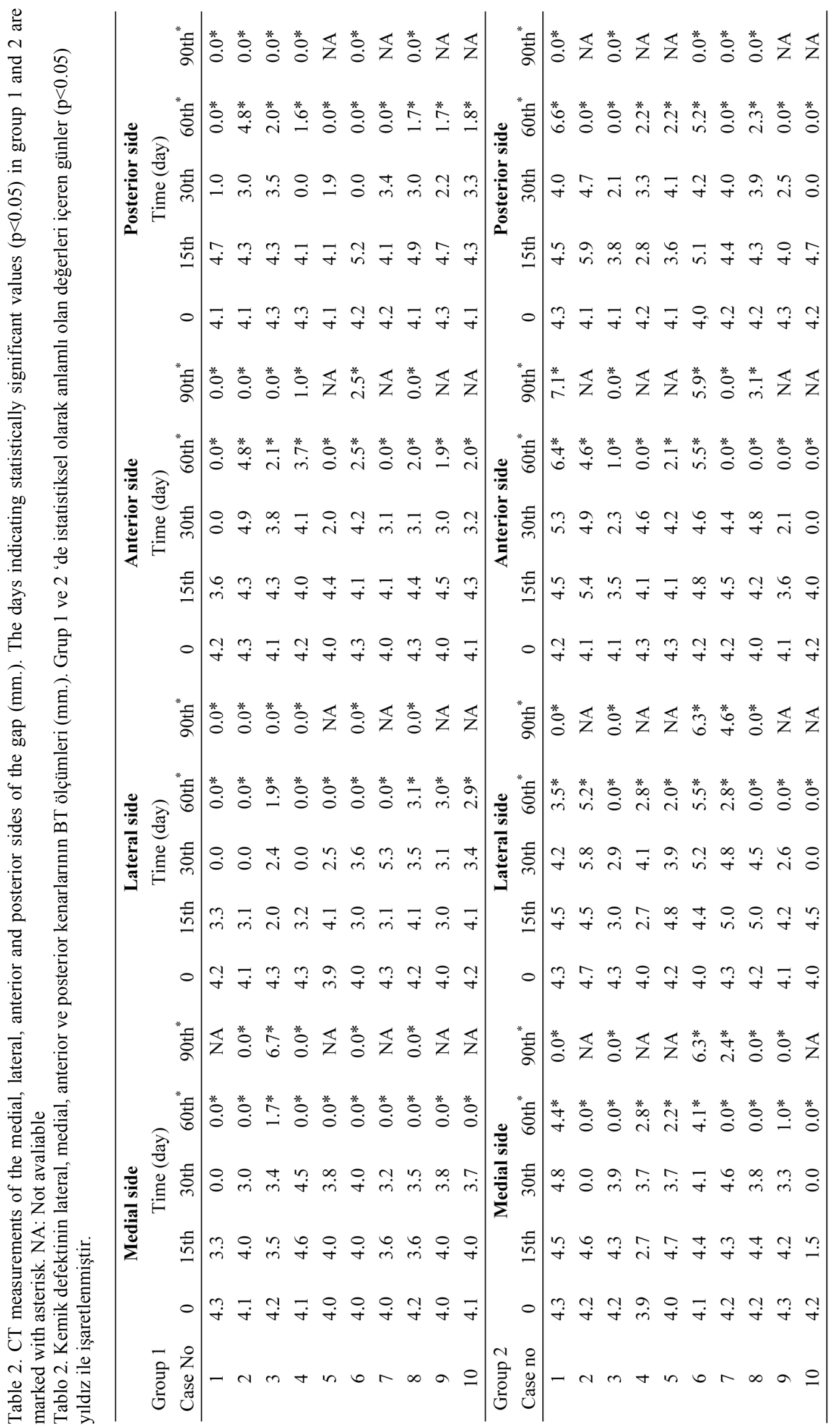




\section{Three Dimensional CT Results}

Group 1: No difference was found on the posterior, anterior, lateral, and medial distances of the gap on days 0,15 , and 30; however, the gap distance was significantly closed on days 60 and 90 compared to that on days 0,15 , and $30(\mathrm{p}<0.05)$. Significant increase of the density was observed on day 60 than on days 0,15 , and 30 . The union of at least 3 sides of the gap was observed in $10 \%$ $(n=1), 40 \%(n=4)$, and $100 \%(n=6)$ of the rabbits on postoperative days 30, 60, and 90, respectively (Figure 2).

Group 2: No difference was found on the posterior, anterior, lateral, and medial distances of the ostectomy site on postoperative days 0,15 , and 30 ; however, the gap distance was significantly closed on days 60 and 90 than other 0,15 , and 30 days $(p<0.05)$. There was no significant difference in density between the results of 0th, 15th, 30th, 60th, and 90th days. The union of at least 3 sides of the gap was observed in $10 \%(\mathrm{n}=1), 40 \%$ $(\mathrm{n}=4)$ and $60 \%(\mathrm{n}=3)$ of the rabbits on days 30,60 , and 90 , respectively.

The CT results are presented in table 2.

\section{Discussion and Conclusion}

Some clinical studies have shown that the PRP enhances the bone healing when used in association with cancellous bone grafts (14). PRP appears to have a positive effect during the early phases of bone healing when applied with autogenous cancellous bone grafts ( 7 , $10,22)$. When mixed with an autogenous bone graft and activated, the PRP gel containing cytokines and growth factors mandatory for the improvement of wound healing, vascularity and tissue regeneration $(2,22)$. In a study, PRP increased bone formation when used together with bovine cancellous blocks in a non-critical-sized bone defect in the rabbit cranium (1). The results of this study showed that, no beneficial effect of PRP on bone formation was observed. This final result could be explained with several factors.

Platelet concentration in the PRP is recommended as three to five times its original concentration in whole blood or more than $1 \times 10^{6} / \mathrm{ml}(3,14,18)$. However, there is no definite consensus on the optimum platelet concentration $(3,8,18)$. In our study, the mean platelet concentration was $1.206 .000 / \mathrm{mm}^{3}$ and in consistence with literatures; but there was a major difference between the lowest and the highest cell numbers in PRP.

The composition of PRP varies with the preparation technique used. Although all PRP preparations contain a basic set of growth factors, the relative concentration of each factor can differ among preparations. Moreover, the proteases present in the platelet releasate may degrade some of the growth factors (21), which reduces the availability of bioactive factors and changes the composition of the PRP, altering its clinical effectiveness for specific applications. We have noted mild liquefaction during application of autogenous cancellous graft into the PRP. This could affect the concentration of PRP, in addition to altering its osteogenic performance in a negative manner.

Sarkar et al. (20) has explained the failure of PRP as being caused by the fact that the potency of the growth factors liberated by PRP is too weak to induce bone formation in defects with low regeneration capacity. Moreover, the procedures like reaming of the tibia, before implanting the intramedullary nail thus creating a defect, could have negative effect on bone healing. In the presented study, the bone was stabilized using the external fixation method, which was applied percutaneously. In this stabilization method, vascularization and periosteal function are affected minimally (13); therefore, the argument about negative effects of the stabilization procedure is not valid for this study.

The common impediment in the studies conducted on long bones is the lower vascularity and regeneration capacity of the diaphysis $(10,19,20)$. The positive effect of PRP is reported in two studies in which the radius and femur are used $(10,19)$. The radius is not fixed after osteotomy because of the fibro-osseous union of ulna and radius (10). The lack of overlying muscle on the tibia reduces the contribution of the extraosseous circulation in the early stages of fracture healing (4). Lower levels of vasculature of tibia could be the main reason for the negative effect of PRP when compared with the studies in which the radius and femur were used $(10,19)$.

Choi and Mooren et al. $(5,18)$ applied cancellous bone to a defect after grinding in a bone mill. Moreover, Mooren et al., (18) disconnected the cortical bone from the cancellous bone using an osteotome. In our study, the autogenous cancellous bone was obtained from the iliac crest with bone rongeurs, and the cortical bone was removed by a blade and then applied on the PRP gel. Although ineffectiveness of autogenous cancellous bonePRP mixture has been reported $(5,18)$, this procedure could prevent the liquefaction of PRP and maintain the uniformity of the mixture; consequently, the standardized method is used for the study. Liquefaction should be the main aim of future studies because it can affect the influence of the PRP on autogenous cancellous bone grafts and bone-regeneration capacity; in addition, platelets and platelet-derived growth factors are known to act during only the early stages of bone-graft healing because the life span of a platelet in a wound and the period of the direct influence of its growth factors is less than 5 days (15).

In conclusion, this study showed that PRP could not enhance the bone regeneration in long-bone defects when used with autogenous cancellous bone grafts. However, 
further studies should be planned on long bones, which also include histomorphometric evaluation in addition to radiography and $\mathrm{CT}$.

\section{Acknowledgements}

This study was supported by Ondokuz Mayis University Scientific Research Foundation.

\section{References}

1. Aghaloo TL, Moy PK, Freymiller EG (2004): Evaluation of platelet-rich plasma in combination with anorganic bovine bone in the rabbit cranium: A pilot study. Int J Oral Maxillofac Implants, 19, 59-65.

2. Akca K, Cehreli M, Demiralp B, Guzel E, Dagdeviren A (2007): Platelet-rich plasma and bone healing: A histologic study in titanium bone chambers. Int J Periodontics Restorative Dent, 27, 387-392.

3. Borzini P, Mazzucco L (2007): Platelet- Rich plasma $(P R P)$ and platelet derivatives for topical therapy. What is true from the biological wiev point? ISBT Sci Ser, 2, 272281.

4. Boudrieau RJ (2002): Fractures of the tibia and fibula. 2144. In: Slatter D. (Ed), Textbook of Small Animal Surgery. Saunders Co., New York.

5. Choi BH, Im CJ, Huh JY, Suh JJ, Lee SH (2004): Effect of platelet-rich plasma on bone regeneration in autogenous bone graft. Int J Oral Maxillofac Surg, 33, 5659.

6. Dallari D, Fini M, Stagni C, Torricelli P, Nicoli Aldini N, Giavaresi G, Cenni E, Baldini N, Cenacchi A, Bassi A, Giardino R, Fornasari PM, Giunti (2006): In vivo study on the healing of bone defects treated with bone marrow stromal cells, platelet-rich plasma, and freezedried bone allografts, alone and in combination. J Orthop Res, 24, 877-888.

7. Dugrillon A, Klüter H (2002): Topical application of platelets for improved wound healing. Blood Ther Med, 3, 21-26.

8. Hatakeyama M, Beletti ME, Zanetta-Barbosa D, Dechichi P (2008): Radiographic and histomorphometric analysis of bone healing using autogenous graft associated with platelet-rich plasma obtained by 2 different methods. Oral Surg Oral Med Oral Pathol Oral Radiol Endod, 105, 13-18.

9. John PWM (1971): Statistical Design and Analysis of Experiments. Siam, Philadelphia.

10. Kasten P, Vogel J, Geiger F, Niemeyer P, Luginbühl R, Szalay K (2008): The effect of platelet-rich plasma on healing in critical-size long-bone defects. Biomaterials, 29, 3983-3992.

11. Katz MH, Alvarez AF, Kirsner RS, Eaglstein WH, Falanga V (1991): Human wound fluid from acute wounds stimulates fibroblast and endothelial cell growth. J Am Acad Dermatol, 25, 1054-1062.
12. Lane JM, Sandhu HS (1987): Current approaches to experimental bone grafting. Orthop Clin North Am, 18, 213-225.

13. Marcellin-Little DJ (2002): External skeletal fixation. 1820-1826. In: Slatter D. (Ed), Textbook of Small Animal Surgery. Saunders Co., New York.

14. Marx RE, Carlson ER, Eichstaedt RM, Schimmele SR, Strauss JE, Georgeff KR (1998): Platelet-rich plasma: Growth factor enhancement for bone grafts. Oral Surg Oral Med Oral Pathol Oral Radiol Endod, 85, 638-646.

15. Marx RE (2001): The biology of platelet-rich plasma. J Oral Maxillofac Surg, 59, 1119-1121.

16. Mehta S, Watson JT (2008): Platelet rich concentrate: Basic science and current clinical applications. J Orthop Trauma, 22, 432-438.

17. Messora MR, Nagata MJ, Dornelles RC, Bomfim SR, Furlaneto FA, de Melo LG, Deliberador TM, Bosco AF, Garcia VG, Fucini SE (2008): Bone healing in criticalsize defects treated with platelet-rich plasma activated by two different methods. A histologic and histometric study in rat calvaria. J Periodontal Res, 43, 723-729.

18. Mooren RE, Merkx MA, Bronkhorst EM, Jansen JA, Stoelinga PJ (2007): The effect of platelet-rich plasma on early and late bone healing: An experimental study in goats. Int J Oral Maxillofac Surg, 36, 626-631.

19. Rai B, Oest ME, Dupont KM, Ho KH, Teoh SH, Guldberg RE (2007): Combination of platelet-rich plasma with polycaprolactone-tricalcium phosphate scaffolds for segmental bone defect repair. J Biomed Mater Res A, 81, 888-899.

20. Sarkar MR, Augat P, Shefelbine SJ, Schorlemmer S, Huber-Lang M, Claes L, Kinzl L, Ignatius A (2006): Bone formation in a long bone defect model using a platelet-rich plasma-loaded collagen scaffold. Biomaterials, 27, 1817-1823.

21. Thibault L, Beausejour A, de Grandmont MJ, Lemieux R, Leblanc JF (2006): Characterization of blood components prepared from whole-blood donations after a 24-hour hold with the platelet-rich plasma method. Transfusion, 46, 1292-1299.

22. Wiltfang J, Kloss FR, Kessler P, Nkenke E, SchultzeMosgau S, Zimmermann R, Schlegel KA (2004): Effects of platelet-rich plasma on bone healing in combination with autogenous bone and bone substitutes in critical-size defects. Clin Oral Implants Res, 15, 187-193.

Geliş tarihi: 16.02.2009 / Kabul tarihi: 12.06.2009
Adress for correspondence
Ahmet Özak DVM, PhD,
Department of Surgery,
Faculty of Veterinary Medicine,
Ondokuz Mayıs University,
55139 Kurupelit/Samsun/Turkey
e-mail:aozak@hotmail.com 